\title{
Analisis Pola Kemitraan Bibit Albesia antara CV Flora Bali di Kabupaten Karangasem dengan UD Tunas Jaya di Kabupaten Klungkung
}

\author{
Made Ngurah Sabda Winaya, Ni Wayan Putu Artini, \\ Putu Udayani Wijayanti
}

Program Studi Agribisnis, Fakultas Pertanian, Universitas Udayana

Jl. PB. Sudirman Denpasar 80332

Email : sabda_winaya@yahoo.com

putuartini@unud.ac.id

\begin{abstract}
Analysis of Albesia Seed Pathership Pattern Between CV Flora Bali in Karangasem Regency with UD Tunas Jaya in Klungkung Regency
\end{abstract}

Cultivation of forest crops can involve various parties, among others, business entities, government, non-governmental organizations and private parties One of the private parties who market forest tree seeds is UD Tunas Jaya. Business partnership relationship between UD Tunas Jaya with CV. Flora Bali in its journey there has been no further analysis of the mechanism of partnership and what benefits have been obtained. This study aims to determine the pattern of partnership business seeds of forest plants between CV. Flora Bali with UD.Tunas Jaya in Pempatan Village, Rendang Sub-district, Karangasem Regency. This research is descriptive conducted at CV Flora Bali and Tunas Jaya by collecting data through in-depth interview and observation. Quantitative data analysis is done by using analysis of farming. The result of the research shows the partnership pattern that has been done between CV Flora Bali and UD Tunas Jaya in the form of Subcontract which is the pattern of partnership relationship between the business partner company that is UD Tunas Jaya with the business partner that produces the seed of forest plant that is CV Flora Bali. The distinctive feature of this subcontract partnership form is to make a joint contract that includes volume, price and time. CV Flora Bali with UD Tunas Jaya in the subcontract partnership pattern is the increase of productivity, labor efficiency and time, the seeds produced in the quality, quantity, and continuity are acceptable to the consumer, social relationships, and increase the income and welfare for the perpetrator Partnership.

Keyword : parthership pattern, forest plant seeds, profit, total cost, net income 


\section{Pendahuluan}

\subsection{Latar Belakang}

Zaman globalisasi sektor pertanian adalah salah satu sektor yang sangat penting bagi negara-negara berkembang termasuk Indonesia. Kenyataannya sektor pertanian memiliki peran penting dalam menopang pembangunan ekonomi di Indonesia. Salah satu dari subsektor pertanian adalah sektor kehutanan. Sektor kehutanan memiliki fungsi sebagai penyuplai oksigen sebagai sirkulasi udara. Hutan juga merupakan sumberdaya alam yang memberikan manfaat besar bagi kesejahteraan manusia. Hutan memiliki manfaat langsung seperti penyediaan kayu, satwa, dan hasil tambang. Hutan menjadi media hubungan timbal balik antara manusia dan makhluk hidup lainnya dengan faktor-faktor alam yang terdiri dari proses ekologi dan merupakan suatu kesatuan siklus yang dapat mendukung kehidupan (Reksohadiprojo, 2000). Seiring perkembangan jaman, di Indonesia terjadi banyak kasus penebangan liar hutan atau illegal loging. Alih fungsi lahan hutan menjadi pemukiman adalah kasus lain dari kerusakan lingkungan hutan. Hal ini terjadi karena nilai ekonomi hasil hutan yang tinggi, membuat oknum-oknum yang tidak bertanggungjawab, dengan sewenangwenang mengeksploitasi hutan untuk kepentingan pribadinya sendiri. Adanya perubahan iklim atau yang sering disebut global warming yaitu salah satu sebagai akibat dari semakin menurun luas kawasan hutan. Faktor-faktor penyebab rusaknya hutan dan meluasnya lahan kritis diantaranya yaitu pembalakan liar, kebakaran hutan, ataupun alih fungsi lahan sebagai akibat dari desakan ekonomi masyarakat terutama di sekitar hutan.

Luas kawasan hutan Indonesia tahun 2015 mencapai 129 juta ha (Badan Pusat Statistik, 2015). Menurut catatan Kementrian Kehutanan Republik Indonesia kerusakan hutan Indonesia sedikitnya 1,1 juta hektar atau 2\% dari hutan Indonesia menyusut tiap tahunnya. Keadaan hutan Indonesia yang kritis, dan mengalami penurunan luas hutan setiap tahunnya, berdampak pada potensi bencana alam seperti, banjir dan tanah longsor. Pemerintah Indonesia menyelenggarakan program reboisasi nasional secara besar-besaran untuk mencegahnya kerusakan hutan dan potensi bencana yang lebih lanjut. Program nasional tersebut adalah menanam 1 milyar bibit pohon hutan setiap tahunnya diseluruh wilayah provinsi Indonesia pada lahan kritis. Program nasional penanaman 1 milyar pohon ini sudah tercantum dalam Peraturan Menteri Kehutanan Republik Indonesia Nomor : P.41/Menhut-II/2013 tentang Panduan Penanaman Satu Milyar Pohon. Peraturan Mentri Kehutanan tersebut mewajibkan seluruh provinsi mengadakan penanaman pohon kehutanan termasuk di provinsi Bali.

Menurut data Dinas Kehutanan Provinsi Bali memiliki luas kawasan hutan 130.686 ha. Penanaman bibit tanaman hutan yang telah direalisasi dalam program Satu Milyar Pohon Provinsi Bali selama tahun 2015 pada setiap kabupaten/ kota. realisasi penanaman 1 milyar pohon di Provinsi bali sebesar 9.755.541 bibit. Data dari Dinas Kehutanan Provinsi Bali idealnya kebutuhan bibit tanaman hutan sesuai di wilayah kawasan hutan Bali adalah kurang lebih 210 juta bibit. Usaha pembibitan tanaman hutan dapat melibatkan berbagai pihak antara lain badan usaha, pemerintah, lembaga swadaya masyarakat maupun pihak swasta. Salah satu pihak swasta yang memasarkan bibit 
tanaman hutan adalah UD Tunas Jaya. UD Tunas Jaya adalah sebuah usaha dagang yang bergerak dalam penjualan berbagai bibit tanaman, salah satu produknya adalah bibit tanaman hutan.

Pihak UD Tunas Jaya tidak mampu memproduksi sendiri bibit pohon dan mencari mitra kerja kepada produsen bibit tanaman hutan di daerah luar kota Denpasar. Salah satu mitra kerjanya adalah CV. Flora Bali untuk membuat bibit tanaman hutan yang terletak di Banjar Kubakal, Desa Pempatan, Kecamatan Rendang, Kabupaten Karangasem. Pihak UD Tunas Jaya baru menjalin kemitraan dengan CV. Flora Bali dari bulan November tahun 2012. CV. Flora Bali ini juga mengalami kesulitan dalam pemasaran produk bibitnya yang masih dijual di wilayah lokal Kabupaten Karangasem saja serta memproduksi bibit saat ada pembeli yang memesan. Hubungan kemitraan bisnis yang terjalin antara UD Tunas Jaya dengan CV. Flora Bali dalam perjalanannya belum ada analisis lebih lanjut tentang mekanisme kemitraannya serta manfaat-manfaat apa saja yang telah diperoleh. Mempertimbangkan hal tersebut dilakukan penelitian tentang pola kemitraan dari kegiatan produksi bibit tanaman hutan dari CV. Flora Bali dengan UD Tunas Jaya dalam hal pemasarannya.

\subsection{Tujuan Penelitian}

Tujuan penelitian ini adalah mengetahui mekanisme pola kemitraan antara CV. Flora Bali pada UD Tunas Jaya, besar penerimaan dan pendapatan penjualan bibit albesia, serta manfaat yang diterima dengan melakukan kemitraan.

\section{Metode Penelitian}

\subsection{Lokasi dan Waktu Penelitian}

Penelitian ini dilakukan di CV. Flora Bali di Desa Pempatan, Kecamatan Rendang, Kabupaten Karangasem, dan di UD. Tunas Jaya di Desa Dawan Kelod, Kecamatan Dawan, Kabupaten Klungkung dengan waktu penelitian dimulai dari bulan Januari sampai bulan Juli 2017. Pemilihan lokasi penelitian tersebut dilakukan secara purposive yaitu pemilihan lokasi secara sengaja dengan pertimbangan CV. Flora Bali mengusahakan bibit tanaman hutan yang diperlukan UD Tunas Jaya sejak bulan April tahun 2012.

\subsection{Populasi dan Sampel}

Populasi adalah keseluruhan unit analisis yang ciri - cirinya akan diduga. Sampel adalah bagian dari populasi yang disediakan untuk penelitian. Populaasi dalam penelitian ini adalah seluruh seluruh pegawai dari CV Flora Bali dan UD Tunas Jaya. Seluruh populasi dijadikan sampel didata secara sensus yang menjadi responden penelitian. Responden dari CV Flora Bali sebanyak empat orang dan responden UD Tunas Jaya sebanyak delapan orang 


\subsection{Sumber, Jenis dan Metode Pengumpulan Data \\ 2.3.1 Sumber dan jenis data}

Sumber data terdiri dari 2 jenis yaitu data primer diperoleh dengan cara melakukan pengukuran dan wawancara secara langsung kepada responden dengan menggunakan pedoman wawancara di lapangan yaitu dari pihak CV Flora Bali dan dari pihak UD Tunas Jaya. Jenis data yang dikumpulkan seperti data biaya-biaya usaha yang dikeluarkan selama proses produksi sampai ke pemasaran serta data hasil pendapatan atau laba yang diterima. Data sekunder diperoleh dengan dari berbagai instansi, bukubuku, informasi dari internet dan laporan hasil penelitian lain, serta cara mengutip arsip perusahaan dan literatur yang terkait dengan penelitian ini.

Jenis data terdiri dari dua jenis yaitu data kuantitatif, adalah data dalam bentuk angka dan bisa dihitung seperti jumlah produksi, luas lahan, harga jual, tenaga kerja, jumlah biaya usaha, serta tingkat pendapatan atau laba. Data kualitatif, adalah data yang tidak berbentuk angka melainkan berbentuk kata, kalimat, gambar, skema, maupun keterangan yang berkaitan dengan penelitian seperti data gambaran umum CV Flora Bali dan UD Tunas Jaya, alasan pihak bermitra masalah, dan kendala yang terjadi serta manfaat dari melakukan kemitraan.

\subsubsection{Metode Pengumpulan data}

Metode yang digunakan dalam penelitian ini dikumpulkan dengan menggunakan teknik: wawancara mendalam, yaitu berupa tanya jawab dengan responden dari pihak CV Flora Bali dengan UD Tunas Jaya menggunakan pedoman wawancara. Observasi, yaitu memperoleh data dengan melihat dan mengamati objek penelitian secara langsung, kegiatan ini dilakukan untuk memperoleh gambaran tentang objek serta mendukung validasi metode wawacara. Studi pustaka (research library) yaitu mengambil data-data sekunder dari berbagai sumber (buku-buku, teks, jurnal, dan informasi internet) yang dibutuhkan dalam penelitian ini. Dokumentasi, yaitu pengumpulan data penelitian dengan cara mencatat dokumen (laporan keuangan, kuitansi penjualan, dll) serta foto-foto yang berhubungan dengan penelitian.

\subsection{Variabel Penelitian dan Pengukuran}

Variabel yang dianalisis dalam penelitian ini adalah (1) pola kemitraan, (2) pendapatan dan penerimaan bibit albesia, dan (3) manfaat kemitraan. Pola kemitraan terdiri dari jenis pola kemitraan dan mekanisme kemitraan. Pendapatan dan penerimaan bibit albesia terdiri dari jumlah produk bibit yang dijual, harga jual bibit, serta total biaya. Manfaat kemitraan terdiri dari jaminan kuantitas dan kualitas, kontinuitas, dan sosial.

\subsection{Metode Analisis Data}

Penelitian ini untuk menganalisis data melalui tiga tahap sesuai tujuan penilitian yang akan dicapai yaitu sebagai berikut : menguji permasalahan pertama tentang 
mekanisme pola kemitraan yaitu dengan pendekatan analisis deskriptif. Pendekatan deskritif merupakan cara pemecahan masalah dengan mendeskripsikan kondisi subyek dan objek penelitian. Mengetahui penerimaan dan pendapatan yang diperoleh oleh CV Flora Bali dan UD Tunas Jaya dilakukan analisis usahatani. Analisis usaha tani yaitu penerimaaan dikurangi semua biaya yang dikeluarkan dengan rumus sebagai berikut (Soekartawi, 1995) :$$
=\mathrm{Q} \cdot \mathrm{P}
$$

$(\mathrm{Pd})=\mathrm{TR}-\mathrm{TC}$

$\mathrm{TC}=\mathrm{TFC}+\mathrm{TVC}$

Keterangan :

$\mathrm{Pd}=$ pendapatan/keuntungan

$\mathrm{TR}=$ total penerimaan

$\mathrm{TC}=$ total biaya yang dikeluarkan/ total cost

$\mathrm{Q}=$ Quantity/ jumlah produksi bibit tanaman hutan

$\mathrm{P} \quad=$ Price/harga jual

TFC = total biaya tetap/ total fixed cost

$\mathrm{TVC}=$ total biaya variabel/ total variable cost

Mengetahui manfaat dari melakukan kemitraan dengan dilakukan analisis data secara deskriptif.

\section{Hasil dan Pembahasan}

\subsection{Karakteristik Responden}

Karakteristik responden yang dijelaskan antara lain : jenis kelamin, umur, dan tingkat pendidikan. Responden CV Flora Bali terdiri dari tiga responden laki-laki dan satu responden perempuan. Responden UD Tunas Jaya terdiri dari lima responden lakilaki dan dua responden perempuan.

Karakteristik responden berdasarkan umur dimana klasifikasinya di interval umur $\leq 14$ tahun yang merupakan termasuk kelompok umur untuk bersekolah. Interval umur 15-64 tahun termasuk golongan umur yang produktif atau kelompok umur yang mampu melakukan aktivitas yang menghasilkan produk barang dan jasa. Interval umur $65 \geq$ tahun termasuk golongan umur tidak produktif dan bisa diartikan kelompok umur senja atau tua.

Karakteristik responden menurut tingkat pendidikan sangat penting dimana dapat diartikan semakin tinggi tingkat pendidikan seseorang maka semakin produktif kemampuan seseorang serta bisa mengambil resiko dan membuat keputusan. Tingkat pendidikan dari responden CV Flora terdiri dari dua orang tingkat SMP dan dua orang tingkat SMA. Responden pada UD Tunas Jaya terdiri dari tiga orang tingkat pendidikan SMA dan 4 orang tingkat pendidikan Sarjana. 


\subsection{Pelaksanaan Program Kemitraan CV. Flora Bali dengan UD Tunas Jaya}

Pelaksana kemitraan dalam jual beli bibit tanaman hutan yang dilakukan oleh CV Flora Bali dan UD Tunas Jaya, dimana kemitraan mulai terjalin sejak dibuatkan kontrak perjanjian transaksi tanggal 5 April tahun 2012 sampai sekarang. Kemitraan ini dimulai dari sebagai pengusaha bibit tanaman termasuk bibit tanaman hutan Pak Gede Natih sebagai pemilik UD Tunas Jaya kesulitan dalam memenuhi permintaan kuantitas bibit tanaman hutan dari konsumen. Dirinya bertemu dengan Pak Wayan Suenda (pemilik CV Flora Bali) untuk ikut membantu atau bermitra dengan bisnis bibit tanaman hutannya. Pak Wayan Suenda bersedia untuk bermitra dengan Pak Gede Natih dalam bisnis bibit tanaman hutan diperjelas pada sebuah kontrak perjanjian jual belinya. Perjalanan dalam menjalin kemitraan bisnis bibit tanaman hutan ini setiap ada pemesanan dari UD Tunas Jaya kepada CV Flora Bali selalu dibuatkannya kontrak perjanjian jual beli terhadap kedua belah pihak seperti yang sudah terlampir.

\subsection{Hak dan Kewajiban masing-masing Pihak Bermitra}

Berikut ini merupakan hak dan kewajiban dari CV Flora Bali dan UD Tunas Jaya yaitu Hak CV. Flora Bali yaitu mendapatakan kejelasan perihal kontrak jual beli bibit tanaman hutan seperti bibit albesia, mendapatkan pengarahan terhadap produksi bibit dari UD Tunas Jaya, mendapat uang muka untuk biaya produksi bibit albesia.

Kewajiban pihak CV Flora Bali adalah bertanggungjawab sepenuhnya pada produk bibit, pengemasan distribusi dan surat-menyurat atau dokumen yang harus dibuat oleh UD Tunas Jaya; tidak boleh melanggar perjanjian kontrak jual beli terhadap UD Tunas Jaya serta selalu berkomunikasi kepada UD Tunas Jaya terhadap proses produksi bibit albesia. Hak yang dimiliki UD Tunas Jaya adalah UD Tunas Jaya berhak mendapat bagi hasil dari penjualan bibit yang dihasilkan sesuai dengan kesepakatan, kepastian mendapat bibit dari CV Flora Bali sesuai waktu yang telah disepakati di surat perjanjian kontrak serta hanya menerima bibit albesia yang hidup atau siap dijual dengan kualitas baik. Kewajiban UD Tunas jaya yaitu menunjuk pihak kedua yaitu CV Flora Bali untuk membuat bibit tanaman hutan yang bersertifikat yang asal-usulnya benihnya jelas, menunjuk pihak kedua yaitu CV Flora Bali sebagai tenaga teknis persemaian serta UD Tunas Jaya berkewajiban memberikan sarana produksi seperti : benih bersertifikat dan lain-lain sesuai kebutuhan yang dimohonkan pihak CV Flora Bali, serta UD Tunas Jaya berkewajiban memasarkan hasil produksi dari CV Flora Bali, UD Tunas Jaya berkewajiban melakukan pendampingan, pelatihan, dan administrasi yang dibutuhkan oleh CV Flora Bali.

\subsection{Pola Kemitraan yang Terjalin antara CV Flora Bali dengan UD Tunas Jaya}

Kemitraan merupakan strategi bisnis yang dilakukan oleh dua pihak atau lebih dalam jangka waktu tertentu untuk meraih keuntungan bersama dengan prinsip saling membutuhkan dan saling membesarkan (Hafsah : 2000). Menurut Undang-Undang No. 
9 Tahun 1995 yang dimaksud dengan kemitraan adalah kerjasama antara pengusaha kecil dengan usaha menengah atau dengan usaha besar disertai pembinaan dan pengembangan yang berkelanjutan oleh usaha menengah atau usaha besar dengan memperhatikan prinsip saling memerlukan memperkuat dan saling menguntungkan. Kontrak kerjasama ini bukan hanya berupa memorandum of understanding namun kontrak kerjasama sudah memuat perjanjian waktu, harga, jumlah produksi, yang dibarengi dengan sanksi yang ditetapkan apabila salah satu pihaknya melanggar atau merugikan pihak lain (Yotopoulus, 1976). Setiap kegiatanabisnis/ usaha selalu ada resiko. Satu norma yang dianut oleh dunia usaha bahwa keuntungan/ kesuksesan besar biasanya mengandung konsekuensi resiko yang besar pula (Alexandri, 2008).

Kemitraan yang terjalin antara CV Flora Bali dengan UD Tunas Jaya sejak bulan November 2012. Hasil wawancara dengan responden, maka pola kemitraan yang telah terlaksana antara CV Flora Bali dengan UD Tunas Jaya berbentuk subkontrak yang merupakan pola hubungan kemitraan antara perusahaan mitra usaha yaitu UD Tunas Jaya dengan mitra usaha yang memproduksi bibit tanaman hutan yaitu CV Flora Bali. Ciri khas dari bentuk kemitraan subkontrak ini adalah membuat membuat kontrak bersama yang mencantumkan volume, harga, dan waktu. Kerjasama bisnis bibit albesia ini dimulai dari UD Tunas Jaya yang mendapat konsumen yang memesan produk bibit albesia sesuai dengan permintaannya. Baik dalam hal kuantitas (jumlah bibit albesia yang dipesankan) dan kualitas seperti umur dan rata-rata tinggi bibit albesia. Menjalin kesepakatan jual beli terhadap konsumen yang memesan, UD Tunas Jaya berkomunikasi dengan CV Flora Bali. Selama masa produksi bibit albesia CV Flora Bali kewajiban yang harus dilakukan adalah komunikasi intensif antara kedua belah pihak. Bibit albesia siap jual, CV Flora Bali berkewajiban menghubungi UD Tunas Jaya. UD Tunas Jaya siap mengambil bibit albesia tersebut dari tempat produksi pembibitan albesia di desa Pempatan kecamatan Rendang kabupaten Karangasem dari pihak CV Flora Bali. Bibit albesia tersebut siap jual ke konsumen, akan di cek oleh UD Tunas Jaya yang sesuai kesepakatan yang tercantum di kontrak penjualan. Hasil penjualan yang didapatkan UD Tunas Jaya akan dibagi ke CV Flora Bali sesuai perjanjian kontrak dengan membayar sisa kekurangan pembayaran bibit albesia yang dibeli dari CV Flora Bali

\subsection{Biaya Produksi}

\subsubsection{Biaya produksi bibit CV Flora Bali}

Menurut Lipsey (1995), biaya merupakan pengorbanan sumber ekonomis yang diukur dalam satuan uang yang telah terjadi atau kemungkinan akan terjadi untuk mencapai tujuan tertentu. Biaya produksi adalah biaya yang sangat menunjang proses jalannya kegiatan usahatani. Biaya tersebut terdiri dari biaya tetap dan biaya variabel. Biaya tetap pembuatan bibit Albesia dalam 1 periode produksi sebesar Rp 970.000 terdiri dari biaya paranet, bambu, dan biaya air PDAM. Biaya variabel pembuatan bibit tanaman hutan sebesar Rp 5.850.000 yang terdiri dari biaya pembelian tanah, pupuk kandang dan benih Albesia serta upah tenaga kerja. Biaya ini berdasarkan pada 
pembuatan/ satu kali produksi bibit jenis Albesia pada luas 10 are dengan jumlah produksi 10.000 bibit.

\subsubsection{Biaya produksi UD Tunas Jaya}

Biaya produksi adalah biaya yang sangat menunjang proses jalannya kegiatan usahatani. Biaya tersebut terdiri dari biaya tetap dan biaya variabel. Biaya tetap pembuatan bibit Albesia dalam satu periode produksi sebesar Rp 1.020.000 terdiri dari biaya paranet, bambu dan biaya air PDAM. Biaya variabel sebesar Rp 20.400.000 yang terdiri dari biaya pembelian bibit siap tanam dari CV Flora Bali sebesar Rp 13.500.000, serta biaya upah pemeliharaan dan sewa truk. Biaya ini berdasarkan pada pembelian bibit jenis Albesia dari CV Flora Bali dengan jumlah total 9.000 bibit

\subsection{Penerimaan dan Pendapatan Bersih CV Flora Bali}

Menurut Riyanto (1993), keuntungan merupakan hasil pengurangan dari total penerimaan (total revenue) dengan total biaya yang dikeluarkan (total cost). Menurut Riyanto (1993), keuntungan merupakan hasil pengurangan dari total penerimaan (total revenue) dengan total biaya yang dikeluarkan (total cost). Jumlah total produksi bibit tanaman Albesia yang dibuat oleh CV Flora Bali sebanyak 9.000 bibit. Harga per bibit yang dijual serta dibeli oleh UD Tunas Jaya kepada CV Flora Bali sebesar Rp 1.500,/bibit. Total penerimaan yang didapatkan oleh CV Flora Bali sebesar Rp 13.500.000. Pendapatan bersih yang diperoleh sebesar $\mathrm{Rp} 6.680 .000$, dimana total penerimaan 13.500 .000 dikurang total biaya 6.680.000,-

\subsection{Penerimaan dan Pendapatan Bersih UD Tunas Jaya}

Pembelian bibit tanaman Albesia ke CV Flora Bali oleh UD Tunas Jaya sebanyak 9.000 bibit. Harga per bibit yang dibeli oleh UD Tunas Jaya kepada CV Flora Bali sebesar Rp 1.500,/bibit, dan kemudian UD. Tunas Jaya menjual kembali kepada konsumen sebesar Rp 3.000,/bibit. Maka dari itu total keuntungan yang diperoleh UD Tunas Jaya untuk penjualan satu bibit ke konsumen sebesar Rp 1.500,00/bibit. Total penerimaan yang didapatkan oleh UD Tunas Jaya sebesar Rp 27.000.000. Pendapatan bersih yang diperoleh sebesar Rp 5.580.000, dimana total penerimaan 27.000.000 dikurang total biaya 21.420.000,-

\subsection{Manfaat Kemitraan yang didapatkan oleh CV Flora Bali dan UD Tunas \\ Jaya}

Manfaat kemitraan adalah produktivitas. Produktifitas meningkat apabila dengan input yang sama dapat diperoleh hasil yang lebih tinggi atau sebaliknya dengan hasil yang sama hanya membutuhkan input yang lebih rendah (Schonberger dan Knod, 1991 ; Chase and Aquilano, 1992). Manfaat yang diperoleh oleh CV Flora Bali dengan UD 
Tunas Jaya dalam pola kemitraan subkontak yang sudah terjalin dari Bulan April 2012 sampai sekarang.

Manfaat bagi CV Flora Bali manfaat yang diperoleh adalah mempunyai kepastian pasar karena bibit tanaman hutan yang diproduksi CV Flora Bali sesuai pesanan dan dalam arti sudah pasti laku, mengurangi resiko bibit tanaman hutan yang tidak terjual, memperoleh tambahan pengetahuan tentang bibit tanaman hutan dari pihak mitra UD Tunas Jaya. Manfaat bagi UD Tunas Jaya adalah kepastian memperoleh atau mendapat ketersediaan bibit tanaman hutan dari pihak mitra CV Flora Bali, UD Tunas Jaya mampu menyediakan atau dapat memperoleh bibit tanaman hutan yang sesuai pesanan konsumen, UD Tunas Jaya mampu memngurangi beban produksi bibit tanaman hutan dari mitraanya CV Flora Bali.

\section{Simpulan dan Saran}

\subsection{Simpulan}

Simpulan dari penelitian ini menunjukkan bahwa pola kemitraan yang terjalin antara CV Flora Bali dengan UD Tunas Jaya berbentuk subkontrak. Pola subkontrak dapat meningkatkan manfaat serta keuntungan dari menambahkan penjualan bibit tanaman dan memperbanyak mempromosikan program penghijauan sehingga memperoleh besar keuntungan per bibit yang dibeli supaya tetap terjalin hubungan sosial dengan baik.

\subsection{Saran}

Peningkatan upaya-upaya untuk meningkatkan pendapatan/keuntungan dengan menambahkan penjualan bibit tanaman hutan dari CV Flora Bali ke UD Tunas Jaya. UD Tunas Jaya dengan memperbanyak mempromosikan program penghijauan sehingga semakin banyak membeli bibit tanaman hutan ke CV Flora Bali

\section{Ucapan Terima Kasih}

Ucapan terimakasih penulis sampaikan kepada Pimpinan CV Flora Bali dan UD Tunas Jaya yang telah memberikan ijin penelitian, serta semua rekan yang telah membantu terselesainya pelaksanaan penelitian ini hingga termuat di e-jurnal

\section{Daftar Pustaka}

Alexandri, Moh. Benny. 2008. Manajemen Keuangan Bisnis. Cetakan Kesatu. Bandung: Alfabeta.

Badan Pusat Statistik. 2012. Luas kawasan Hutan Indonesia Tahun 2015.

Dinas Kehutanan Provinsi Bali. 2015. Luas Kawasan Hutan Provinsi Bali tahun 2015.

Hafsah, Moh. Jafar. 2000. Kemitraan Usaha. Jakarta : Pustaka Sinar Harapan 
Lipsey, Courant, Purvis, Steiner. 1995 Pengantar Mikroekonomi, edisi kesepuluh dialihbahasakan oleh Jaka Wasana dan Kirbrandoko, Harper, dan Row, Binarupa Aksara.

Reksohadiprodjo, s., Brodjonegoro. 2000. Ekonomi Lingkungan. BPFE Yogyakarta. Edisi Kedua. Yogyakarta.

Riyanto, B. 1993. Dasar-Dasar Pembelanjaan Perusahaan. Yayasan Badan. Penerbit Gajah Mada. Yogyakarta.

Schonberger J., Edward M. Knod, Jr. 1991. Operations Management; Improving Custumer Service. Ricard D. Irwin Inc., Boston, USA.

Soekartawi. 1986. Ilmu Usahatani dan Penelitian untuk Pengembangan Petani Kecil. UI Press : Jakarta

Yotopoulus, Pan A dan Jeffrey B. Nugent. 1976, Economic of Development, Empirical Investigations, Harper dan Row Publisher 